University of Nebraska - Lincoln

DigitalCommons@University of Nebraska - Lincoln

Publications from USDA-ARS / UNL Faculty

U.S. Department of Agriculture: Agricultural

Research Service, Lincoln, Nebraska

November 1998

\title{
Comparisons of soil physical characteristics in long-term tillage winter wheat-fallow tillage experiments
}

\author{
L. N. Mielke \\ US. Department of Agriculture, Agricultural Research Service \\ Wallace Wilhelm \\ University of Nebraska-Lincoln, wwilhelm1@unl.edu
}

Follow this and additional works at: https://digitalcommons.unl.edu/usdaarsfacpub

Part of the Agricultural Science Commons

Mielke, L. N. and Wilhelm, Wallace, "Comparisons of soil physical characteristics in long-term tillage winter wheat-fallow tillage experiments" (1998). Publications from USDA-ARS / UNL Faculty. 107. https://digitalcommons.unl.edu/usdaarsfacpub/107

This Article is brought to you for free and open access by the U.S. Department of Agriculture: Agricultural Research Service, Lincoln, Nebraska at DigitalCommons@University of Nebraska - Lincoln. It has been accepted for inclusion in Publications from USDA-ARS / UNL Faculty by an authorized administrator of DigitalCommons@University of Nebraska - Lincoln. 


\title{
Comparisons of soil physical characteristics in long-term tillage winter wheat-fallow tillage experiments
}

\author{
L.N. Mielke, W.W. Wilhelm* \\ U.S. Department of Agriculture, Agricultural Research Senice, 119 Keim Hall, University of Nebraska, Lincoln, NE 68583-0934, USA
}

Received 24 September 1997; accepted 3 April 1998

\begin{abstract}
Soil physical characteristics resulting from tillage of fallow-wheat (Triticum aestivum L.) cropping systems were compared for two soils in western Nebraska. The soil physical environment influences the amount of water entering soil and the microenvironment that influences soil biological processes important to plant response. Effects of tillage on physical properties varied with soil type and depth of soil tillage. Generally, the $0-76 \mathrm{~mm}$ surface layer has the largest number of physical properties that differ as a result of tillage; however, only a few properties differed at greater depths. The Alliance silt loam (fine silty, mixed, mesic, Aridic Arguistoll) soil at the Previously Cultivated site, for example, showed differences in bulk density, hydraulic conductivity, ratio of air to water permeability, and total porosity for the $0-76 \mathrm{~mm}$ layer but only hydraulic conductivity was different at the 76-152 mm depth. A similar frequency of differences in physical properties was also true in the $0-76 \mathrm{~mm}$ layer for the Duroc loam (fine silty, mixed, mesic, Pachic Haplustoll) soil at the Native Sod site. Compared among treatments, water content, bulk density, and pore space differed in the $0-76 \mathrm{~mm}$ layer, while all properties different in the 76-152 mm layer, and there were fewer differences in the 152-304 mm layer in the Native Sod site. The sod treatment usually was the most extreme value with the tillage treatment values clustered together. Air to water permeability ratio, as an indicator of structural stability (ratio of 1 being stable), for the Alliance soil ranged from 18 to 43 in the $0-76 \mathrm{~mm}$ layer and from 31 to 152 in the 76-152 mm layer. For the Duroc soil, the ratio ranged from 5 to 6 in the $0-76 \mathrm{~mm}$ layer and 6 to 22 in the 76-152 mm layer. The Duroc soil has not been cropped as long as the Alliance soil and showed a tendency to be more structurally stable. Based on precipitation intensity records and infiltration characteristics, water would seldom run off the Duroc soil when in sod and with sub-till or no-till. Results show that the runoff would occur most frequently from the plow treatment. (C) 1998 Published by Elsevier Science B.V. All rights reserved.
\end{abstract}

Keywords: Physical properties; Tilled vs. sod; Cropped vs. fallow; Tillage layer; Below tillage depth

\section{Introduction}

The primary reasons for tillage in fallow-wheat cropping systems are for seedbed preparation and weed control. As winter wheat-fallow cropping sys-

\footnotetext{
*Corresponding author. Tel.:+1 402472 1512; fax: +1 402472 0516; e-mail: wwilhelm@unlinfo.unl.edu
}

tems have been developed over the years, some problems have surfaced, such as managing plant residue, adequate weed control, water conservation, and soil erosion control (Lyon et al., 1998; Unger and McCalla, 1980). Tillage equipment has constantly been improved and made more versatile, and producers have become increasingly aware of the benefits of reduced tillage to crop and soil management. 
Fallowing for 14 or more months is a common wheat cropping practice in the Great Plains, where annual precipitation is less than $500 \mathrm{~mm}$. During the fallow period, soil is sometimes left unprotected and is therefore, subject to erosion by strong winds and by intense rain resulting from thunderstorms, both of which are common. Fallowing is practiced to accumulate enough soil water to produce a crop on stored water plus precipitation during the cropping seasons. Often, more than $75 \%$ of the precipitation received during the fallow period is lost to evaporation and leaching in the Central Great Plains (Haas et al., 1974). Superior management is required to achieve even a $25 \%$ water storage efficiency with a black fallow (plow) crop system. Tilling the soil during the fallow period to control weed growth increases loss of soil water by evaporation.

Within the past century, many different kinds of tillage systems have been developed. Dust mulch was used from the late 1800 s to the 1920 s to conserve water. Duley and Russel (1942) developed the stubblemulch fallow tillage system in Nebraska in the late 1930s. Stubble-mulch fallow systems had the advantage of trapping snow, reducing the rate of evaporative water losses, and decreasing runoff and erosion. Fenster et al. (1977) reported stubble mulching, compared to bare soil, resulted in a six-fold decrease in the rate of evaporation during the fallow period and nearly a four-fold decrease during the growing season. They also reported wind erosion losses from bare soil exceeded tolerance levels 2 of 8 years, but erosion losses did not exceed tolerance levels for stubblemulch tillage in any year. Soil water is also conserved with standing stubble. Greb et al. (1967) in Colorado showed that $66 \%$ of snowmelt water was stored in the soil, compared to less than $15 \%$ for a July rainstorm.

Stubble-mulch wheat production techniques improved water conservation and soil erosion control. More recently, developments in herbicide technology have provided opportunities to use chemical weed control for fallow, using little or no tillage. When herbicides replaced tillage on fallow land, weed growth was reduced, and soil water storage and grain yield were increased (Wicks and Smika, 1973). Fenster and Peterson (1979) suggested that herbicides may substitute for soil-disturbing tillage operations, which should enhance water storage through decreased evaporation and reduced soil temperature because of more residue on the surface. In addition, surface residue decreases the diurnal fluctuation in soil temperature, which can influence water movement and storage. Residues protect the soil surface from raindrop impact, generally resulting in less runoff and less soil erosion. The purpose of this research was to compare near surface and below surface soil physical characteristics of plow, sub-till (stubble mulch), and no-till fallow treatments in a winter wheat-fallow rotation and to compare physical characteristics of tilled soil to those of a native sod.

\section{Materials and methods}

\subsection{Field procedures}

Field measurements of the following soil physical characteristics were made: infiltration, air permeability, and water content. Most measurements of soil physical properties were made during the cropping period of the crop-fallow sequence, usually during the spring months. Sampling of fallow conditions were made at the same time as for the cropped site on the Native Sod site in 1982. Bulk density and hydraulic conductivity were determined in the laboratory on undisturbed soil samples collected with a $76 \mathrm{~mm}$ diameter by $76 \mathrm{~mm}$ long sampling cylinder. An Uhland sampler was used to collect soil samples enclosed in aluminum cylinders for determining bulk density of undisturbed soil samples $76 \mathrm{~mm}$ in diameter and $76 \mathrm{~mm}$ in length. Soil sampling was in $76 \mathrm{~mm}$ depth increments to a maximum depth of $304 \mathrm{~mm}$.

Infiltration of water into the soil was determined by the double-cylinder method (Haise et al., 1956), with a 305-mm-diameter inner cylinder driven at least $150 \mathrm{~mm}$ into the soil. The 450 -mm-diameter outer cylinder was driven $100 \mathrm{~mm}$ into the soil. A calibrated Mariotte bottle was used to measure the amount of water entering the soil in the inner cylinder and to maintain a constant water head of $15 \mathrm{~mm}$. The level of water in the inner and outer cylinder was kept about the same to ensure vertical water movement into the soil.

Air permeability in the surface was determined at $76 \mathrm{~mm}$ depth and deeper soil depth with equipment described by Grover (1955) and modified by Tanner and Wengel (1957). After air permeability measurements were completed in the field, all air permeability 
sample cans with intact soil cores contained therein were placed in plastic bags and transported to the laboratory where oven dry soil mass was determined, soil volume measurements, and bulk density calculated. Sample cans used were $65 \mathrm{~mm}$ in diameter and $120 \mathrm{~mm}$ in length.

\subsection{Laboratory procedures}

Volume of soil water and field weight measurements were made on air permeability sample cores. A Dacron polyester fabric was secured under the bottom of the container with a rubber band by holding excess fabric along the sides of the sampler. Samples were wetted from the bottom for $16 \mathrm{~h}$ until fully wet as defined by Miller and Besler (1977), and hydraulic conductivity was determined by the constant head method using tap water. Hydraulic conductivity data were converted to water permeability (Klute, 1965), and air-to-water permeability ratios determined. Total pore space was calculated using measured bulk density and assumed particle density of $2.65 \mathrm{Mg} \mathrm{m}^{-2}$.

\section{Results and discussion}

\subsection{Previously Cultivated site (Alliance soil)}

Soil bulk density was greater for no-till than plow and hydraulic conductivity was less for no-till than sub-till or plow (which did not differ). Bulk density is the inverse of total pore space, therefore, total pore space for no-till was less than for plow and sub-till. Hydraulic conductivity for no-till increased from 3.9 to $6.0 \mathrm{~mm} \mathrm{~h}^{-1}$ from the 0 to $76 \mathrm{~mm}$ depth to 76 $152 \mathrm{~mm}$ depth while hydraulic conductivity for plow and sub-till decreased with each depth increment below the surface. Bulk density and water filled pore space also increased with depth (Table 1).

\subsection{Native Sod site (Duroc soil)}

No-till was wetter and less dense than the plow treatment and therefore had greater total pore space in the $0-76 \mathrm{~mm}$ depth (Table 2). In the 76-152 mm depth, the plow treatment was wetter than the sub-till.

\subsection{Cropped vs. fallow}

Comparisons were made between data from the cropped area (Table 2) and the fallow area (Table 3) for the Duroc soil site in 1982. For the fallow soil one month after tillage, sub-till and plow were drier, less dense, more permeable to air, and had more total pore space and less water filled pore space than no-till in the $0-76 \mathrm{~mm}$ depth. The effects of tillage during fallow (Table 3) had diminished as indicated by trends for cropped conditions for the Duroc soil (Table 2) 13 months after tillage. Bulk density increased for all

Table 1

Physical characteristics of the Previously Cultivated site (Alliance soil), on 12 June 1980 when cropped

\begin{tabular}{|c|c|c|c|c|c|c|c|c|c|}
\hline \multirow[t]{2}{*}{ Treatment } & \multirow{2}{*}{$\begin{array}{l}\text { Water } \\
\text { content }^{\mathrm{a}} \\
\left(\%, \mathrm{w} \mathrm{w}^{-1}\right)\end{array}$} & \multirow{2}{*}{$\begin{array}{l}\text { Bulk } \\
\text { density } \\
\left(\mathrm{Mg} \mathrm{m}^{-3}\right)\end{array}$} & \multirow{2}{*}{$\begin{array}{l}\text { Water } \\
\text { content } \\
\left(\%, \mathrm{v} \mathrm{v}^{-1}\right)\end{array}$} & \multirow{2}{*}{$\begin{array}{l}\text { Hydraulic } \\
\text { conductivity } \\
\left(\mathrm{mm} \mathrm{h}^{-1}\right)\end{array}$} & \multirow{2}{*}{$\begin{array}{l}\text { Air } \\
\text { permeability } \\
\left(\mathrm{pm}^{2}\right)\end{array}$} & \multirow{2}{*}{$\begin{array}{l}\text { Air-to-water } \\
\text { permeability } \\
\text { Ratio }^{b}\end{array}$} & \multicolumn{3}{|c|}{ Pore space $\left(\%, \mathrm{v} \mathrm{v}^{-1}\right)$} \\
\hline & & & & & & & Total & Air filled & Water filled \\
\hline \multicolumn{10}{|c|}{$0-76 \mathrm{~mm}$ depth } \\
\hline Plow & 32.3 & 1.19 & 39.1 & 17.7 & 11.0 & 25.6 & 55.2 & 29.0 & 71.0 \\
\hline Sub-till & 30.9 & 1.23 & 38.1 & 13.8 & 5.6 & 17.7 & 53.4 & 28.7 & 71.3 \\
\hline No-till & 30.9 & 1.27 & 39.3 & 3.9 & 5.2 & 42.7 & 52.1 & 24.3 & 75.7 \\
\hline $\mathrm{LSD}_{0.10}$ & NS & 0.06 & NS & 8.6 & NS & 24.6 & 2.2 & NS & NS \\
\hline \multicolumn{10}{|c|}{ 76-152 mm depth } \\
\hline Plow & 31.9 & 1.29 & 41.0 & 12.9 & 9.1 & 30.9 & 51.2 & 18.0 & 82.0 \\
\hline Sub-till & 30.5 & 1.36 & 41.4 & 2.7 & 5.5 & 105.8 & 48.7 & 14.7 & 85.3 \\
\hline No-till & 31.3 & 1.30 & 40.6 & 6.0 & 6.4 & 151.9 & 51.1 & 19.9 & 80.1 \\
\hline $\mathrm{LSD}_{0.10}$ & NS & NS & NS & 8.7 & NS & NS & NS & NS & NS \\
\hline
\end{tabular}

${ }^{a}$ Volumetric water content, gravimetric water content, and air and water filled pore space represents cores after hydraulic conductivity at $100 \mathrm{~mm}$ water tension.

${ }^{\text {b }}$ Water permeability was calculated from hydraulic conductivity. 
Table 2

Physical characteristics of the native sod site (Duroc soil), on 12 May 1982 when cropped

\begin{tabular}{|c|c|c|c|c|c|c|c|c|c|}
\hline \multirow[t]{2}{*}{ Treatment } & \multirow{2}{*}{$\begin{array}{l}\text { Water }^{\mathrm{a}} \\
\text { content } \\
\left(\%, \mathrm{w} \mathrm{w}^{-1}\right)\end{array}$} & \multirow{2}{*}{$\begin{array}{l}\begin{array}{l}\text { Bulk } \\
\text { density }\end{array} \\
\left(\mathrm{Mg} \mathrm{m}^{-3}\right)\end{array}$} & \multirow{2}{*}{$\begin{array}{l}\text { Water } \\
\text { content } \\
\left(\%, \mathrm{v} \mathrm{v}^{-1}\right)\end{array}$} & \multirow{2}{*}{$\begin{array}{l}\text { Hydraulic } \\
\text { conductivity } \\
\left(\mathrm{mm} \mathrm{h}^{-1}\right)\end{array}$} & \multirow{2}{*}{$\begin{array}{l}\text { Air } \\
\text { permeability } \\
\left(\mathrm{pm}^{2}\right)\end{array}$} & \multirow{2}{*}{$\begin{array}{l}\text { Air-to-water } \\
\text { permeability } \\
\text { ratio }^{\text {b }}\end{array}$} & \multicolumn{3}{|c|}{ Pore space $\left(\%, \mathrm{v} \mathrm{v}^{-1}\right)$} \\
\hline & & & & & & & Total & Air filled & Water filled \\
\hline \multicolumn{10}{|c|}{$0-76 \mathrm{~mm}$ depth } \\
\hline Plow & 15.2 & 1.18 & 18.0 & 31.3 & 4.2 & 4.8 & 55.5 & 67.5 & 32.5 \\
\hline Sub-till & 18.3 & 1.08 & 19.8 & 45.8 & 6.3 & 5.3 & 59.1 & 66.6 & 33.4 \\
\hline No-till & 20.7 & 1.02 & 21.1 & 37.5 & 6.8 & 6.4 & 61.5 & 65.8 & 34.2 \\
\hline Sod & 24.2 & 1.01 & 24.4 & 46.7 & 9.6 & 6.5 & 62.0 & 60.7 & 39.3 \\
\hline $\mathrm{LSD}_{0.10}$ & 2.7 & 0.09 & 2.6 & NS & NS & NS & 3.4 & 5.1 & 5.1 \\
\hline \multicolumn{10}{|c|}{$76-152 \mathrm{~mm}$ depth } \\
\hline Plow & 15.9 & 1.34 & 21.3 & 9.3 & 2.7 & 22.2 & 49.4 & 56.9 & 43.1 \\
\hline Sub-till & 13.2 & 1.36 & 18.0 & 14.9 & 3.0 & 8.7 & 48.6 & 62.6 & 37.4 \\
\hline No-till & 14.3 & 1.32 & 18.9 & 15.4 & 2.4 & 6.5 & 50.2 & 62.4 & 37.6 \\
\hline Sod & 12.7 & 1.26 & 15.9 & 121.5 & 13.6 & 7.7 & 52.3 & 69.7 & 30.3 \\
\hline $\mathrm{LSD}_{0.10}$ & 2.5 & 0.08 & 3.1 & 91.3 & 4.4 & 12.9 & 3.1 & 6.7 & 6.7 \\
\hline \multicolumn{10}{|c|}{$152-304 \mathrm{~mm}$ depth } \\
\hline Plow & 11.0 & 1.35 & 14.9 & 24.7 & 3.7 & 6.0 & 48.9 & 69.6 & 30.4 \\
\hline Sub-till & 10.3 & 1.36 & 14.0 & 28.9 & 4.0 & 5.0 & 48.6 & 71.1 & 28.9 \\
\hline No-till & 11.1 & 1.37 & 15.1 & 29.4 & 5.1 & 6.4 & 48.2 & 68.8 & 31.2 \\
\hline Sod & 9.5 & 1.37 & 12.9 & 59.8 & 5.3 & 3.1 & 48.3 & 73.4 & 26.6 \\
\hline $\mathrm{LSD}_{0.10}$ & 1.4 & NS & 1.5 & 10.4 & NS & 2.4 & NS & 2.6 & 2.6 \\
\hline
\end{tabular}

${ }^{a}$ Volumetric water content, gravimetric water content, and air and water filled pore space represents cores after hydraulic conductivity at $100 \mathrm{~mm}$ water tension.

${ }^{b}$ Water permeability was calculated from hydraulic conductivity.

treatments from the first to second depth and water content decreased slightly with depth for no-till. Water filled pore space increased with depth for plow and sub-till treatments and decreased with no-till. Bulk density and total pore space were only different between tillage treatments in the $76-152 \mathrm{~mm}$ depth and there were no differences in the $152-304 \mathrm{~mm}$ depth.

\subsection{Sod vs. tilled}

Tillage treatment effects generally do not persist much below the tillage zone, however, physical characteristics are influenced by native sod at the 152$304 \mathrm{~mm}$ depth (Tables 2 and 3). In many comparisons the sod and no-till are similar in characteristics or at least the no-till is following a trend from more severe tillage to least tillage as represented by the sod. Water content of the sod is similar between cropped and fallow conditions for each depth.

Other physical characteristics for sod between cropped and fallow conditions followed similar trends for each depth. In general, the effects of sod on the soil physical characteristics are more dramatic because they tend to persist into the $152-304 \mathrm{~mm}$ depth.

Water-filled pore space is a good indicator of water content and degree to which pores are filled (Linn and Doran, 1984). The percent of space filled with water influences the amount and rate of oxygen exchange in the soil. The water content was low for both fallow and cropped conditions and except for the $0-76 \mathrm{~mm}$ layer when cropped, the soil was drier in terms of percent water-filled pore space than the tilled soil.

\subsection{Infiltration}

Infiltration rates are shown in Fig. 1 for Alliance soil cropped in 1979, the Duroc soil cropped in 1980 , and Duroc soil cropped and fallow in 1982. Initial and final infiltration rates were less for the Alliance soil compared to the Duroc soil. With the cropped Duroc soil, tillage ranked in the same order for initial rates and final rates with sod $>$ no-till $>$ plow $>$ sub-till in 
Table 3

Physical characteristics of the native sod site (Duroc soil), on 12 May 1982 when fallow

\begin{tabular}{|c|c|c|c|c|c|c|c|c|c|}
\hline \multirow[t]{2}{*}{ Treatment } & \multirow{2}{*}{$\begin{array}{l}\text { Water }^{\mathrm{a}} \\
\text { content } \\
\left(\%, \mathrm{w} \mathrm{w}^{-1}\right)\end{array}$} & \multirow{2}{*}{$\begin{array}{l}\text { Bulk } \\
\text { density } \\
\left(\mathrm{Mg} \mathrm{m}^{-3}\right)\end{array}$} & \multirow{2}{*}{$\begin{array}{l}\text { Water } \\
\text { content } \\
\left(\%, v^{-1}\right)\end{array}$} & \multirow{2}{*}{$\begin{array}{l}\text { Hydraulic } \\
\text { conductivity } \\
\left(\mathrm{mm} \mathrm{h}^{-1}\right)\end{array}$} & \multirow{2}{*}{$\begin{array}{l}\text { Air } \\
\text { permeability } \\
\left(\mathrm{pm}^{2}\right)\end{array}$} & \multirow{2}{*}{$\begin{array}{l}\text { Air-to-water } \\
\text { permeability } \\
\text { Ratio }^{b}\end{array}$} & \multicolumn{3}{|c|}{ Pore space $\left(\%, \mathrm{v} \mathrm{v}^{-1}\right)$} \\
\hline & & & & & & & Total & Air filled & Water filled \\
\hline \multicolumn{10}{|c|}{$0-76 \mathrm{~mm}$ depth } \\
\hline Plow & 23.0 & 0.91 & 20.9 & 147.6 & 20.1 & 12.9 & 65.7 & 68.3 & 31.7 \\
\hline Sub-till & 26.0 & 0.84 & 21.7 & 234.4 & 35.2 & 6.1 & 68.2 & 68.1 & 31.9 \\
\hline No-till & 29.9 & 1.01 & 30.2 & 39.5 & 4.6 & 6.7 & 61.9 & 51.0 & 49.0 \\
\hline Sod & 25.4 & 0.97 & 24.6 & 35.9 & 6.5 & 6.4 & 63.3 & 61.2 & 38.8 \\
\hline $\mathrm{LSD}_{0.10}$ & 5.1 & 0.12 & 3.3 & 142.8 & 10.9 & NS & 4.7 & 6.1 & 6.1 \\
\hline \multicolumn{10}{|c|}{$76-152 \mathrm{~mm}$ depth } \\
\hline Plow & 18.4 & 1.17 & 21.7 & 34.4 & 6.9 & 12.4 & 55.7 & 60.7 & 39.3 \\
\hline Sub-till & 19.8 & 1.12 & 21.8 & 22.3 & 4.4 & 8.2 & 57.6 & 62.2 & 37.8 \\
\hline No-till & 17.1 & 1.30 & 22.2 & 20.9 & 4.5 & 7.9 & 50.8 & 56.2 & 43.8 \\
\hline Sod & 11.0 & 1.34 & 14.4 & 45.0 & 6.4 & 6.3 & 50.7 & 71.5 & 28.5 \\
\hline $\mathrm{LSD}_{0.10}$ & 4.7 & 0.12 & 5.3 & NS & NS & NS & 4.7 & 10.9 & 10.9 \\
\hline \multicolumn{10}{|c|}{$152-304 \mathrm{~mm}$ depth } \\
\hline Plow & 15.1 & 1.31 & 19.8 & 18.1 & 5.1 & 12.0 & 50.5 & 60.8 & 39.2 \\
\hline Sub-till & 18.3 & 1.30 & 22.7 & 27.3 & 4.3 & 6.1 & 50.9 & 56.3 & 43.7 \\
\hline No-till & 14.3 & 1.35 & 19.2 & 25.4 & 5.7 & 7.9 & 49.1 & 61.0 & 39.0 \\
\hline Sod & 9.1 & 1.32 & 12.1 & 28.2 & 4.3 & 33.4 & 49.6 & 75.6 & 24.4 \\
\hline $\operatorname{LSD}_{0.10}$ & 5.2 & NS & 4.9 & NS & NS & NS & NS & 7.4 & 7.4 \\
\hline
\end{tabular}

${ }^{a}$ Volumetric water content, gravimetric water content, and air and water-filled pore space represents cores after hydraulic conductivity at $100 \mathrm{~mm}$ water tension.

${ }^{\mathrm{b}}$ Water permeability was calculated from hydraulic conductivity.

1980 and 1981. The cropped and fallow areas at the Native Sod site (Duroc soil) were compared in 1982 (Fig. 1(C) and (D)). With fallow (Fig. 1(D)), the initial infiltration rates were greatest for tilled soil, but after about $20 \mathrm{~min}$ the sub-till rate decreased and was less than sod. After $2 \mathrm{~h}$ the rate for sod was the greatest while the rates for tilled soil were decreasing. With sod the initial rate is influenced by stage of crop growth and soil water content. If for example, the soil is dry and the sod has not started to grow or is drought stressed the many spaces around plant stems and root channels can take in a lot of water. However, the initial rate would be much less if the soil has been fairly wet and the sod is actively growing. Tillage operations and cropping practices tend to destroy natural channels of the soil. Crop production practices should promote some of the beneficial characteristics associated with native soil environments.

Data in Fig. 2, taken from the U.S. Department of Commerce (1961) show the amount of precipitation that can be expected in the Panhandle of Nebraska for $0.5-6 \mathrm{~h}$ duration on a 5-year, 25-year and 100-year frequency. Cumulative infiltration curves shown in Fig. 2 can be compared to the probable precipitation return time in years. For example, infiltration into the plow treatment after $0.5 \mathrm{~h}$ for the Duroc soil was $31 \mathrm{~mm}$, which falls between the 5-year and the 25year rainfall frequency with a $0.5 \mathrm{~h}$ duration. Infiltration for the sub-till and no-till treatments exceeded the 100 -year frequency for the $0.5 \mathrm{~h}$ duration, suggesting that, in this climate, tillage methods would affect amount of water lost by runoff in no more than 1 year out of every 5 or more years. Mean water content in the surface $1.2 \mathrm{~m}$ of soil depth before planting was the least for the Plow treatment (Lyon et al., 1998). Even with its slower initial intake rate, the plowed soil can take in most of the rain. Historical records show most of the annual precipitation comes as small events. In 1979, for example, there were only four $24 \mathrm{~h}$ periods when precipitation exceeded $18.0 \mathrm{~mm}$, and only one such event in 1980 .

Water intake during the first $0.5 \mathrm{~h}$ was fairly high and is similar for the respective tillage treatments on Alliance and Duroc soils. Native sod maintained the 

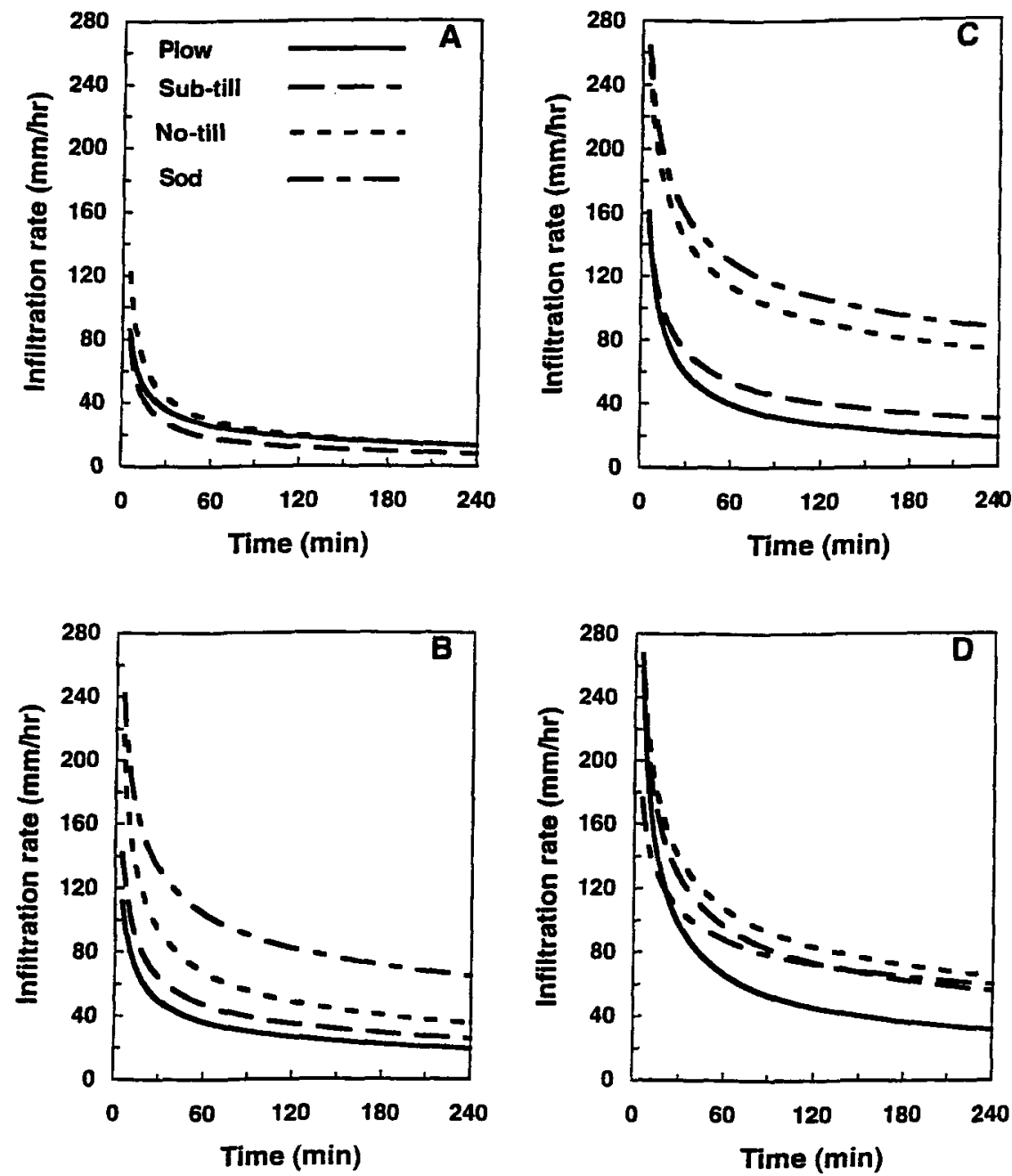

Fig. 1. Infiltration rate for tillage treatments for (a) Alliance soil in 1979; (b) Cropped Durco soil in 1980; (c) Cropped Durco soil in 1982 and (d) Fallow Durco soil in 1982.

highest rate throughout and was higher than the other tillage treatments at $1 \mathrm{~h}$ through $4 \mathrm{~h}$. The effects of tillage on infiltration compared to native sod condition are illustrated in Fig. 2.

\section{Conclusions}

Each soil series has specific soil physical characteristics. In addition, the tillage methods used over time and the crop management history can change soil physical characteristics. In the Previously Cultivated site, surface $152 \mathrm{~mm}$ depth most physical characteristics were the same for the tillage treatments. In the Native Sod site most the physical characteristics were different between tillage treatments and native sod was usually at the extreme range of values. Infiltration of water is affected by several soil characteristics. Infiltration rate curves for the tillage treatments on the Previously Cultivated site show no separation. For the native sod site, infiltration rates were generally largest for sod and decreased as the tillage method with greater amount of soil disturbance increased. The infiltration rate pattern resulting from tillage during 


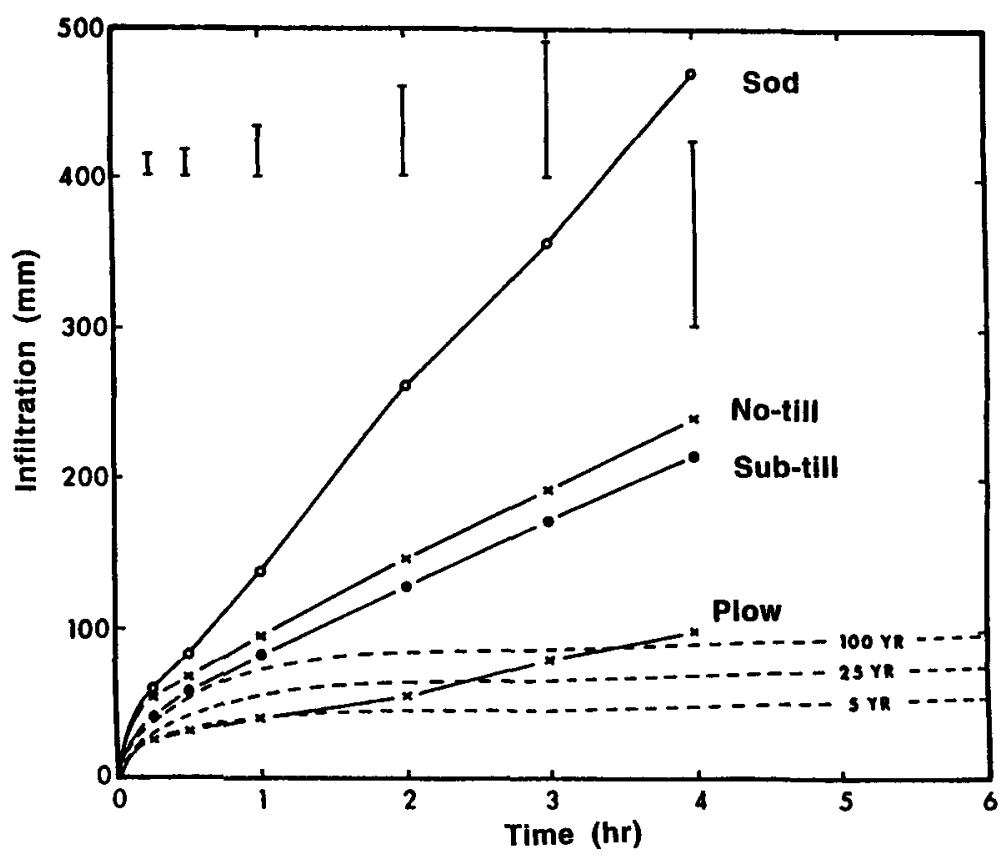

Fig. 2. Cumulative infiltration for fallow tillage methods for Durco loam near Sidney, Nebraska, compared to precipitation amounts for 5-, 25-, and 100-year return frequency. Bars are the $\operatorname{LSD}_{(0.10)}$ values (after Mielke et al., 1984).

fallow period was influenced probably by timing of recent tillage during fallow.

\section{References}

Duley, F.L., Russel, J.C., 1942. Machinery requirements for farming through crop residues. Agric. Eng. 23, 39-72.

Fenster, C.R., Owens, H.I., Follett, R.H., 1977. Conservation tillage for wheat in the Great Plains. PA-1190 USDA Ext. Serv.

Fenster, C.R., Peterson, G.A., 1979. Effects of no-tillage fallow as compared to conventional tillage in a wheat-fallow system. Res. Bull. No. 289, University of Nebraska, Lincoln.

Greb, B.W., Smika, D.E., Black, A.L., 1967. Effect of straw mulch rates on soil water storage during the summer fallow period in the Great Plains. Soil Sci. Soc. Am. Proc. 31, 556-559.

Grover, B.L., 1955. Simplified air permeameters for soil in place. Soil Sci. Soc. Am. Proc. 19, 414-418.

Haas, H.J., Willis, W.O., Bond, J.J., 1974. Summer fallow in the Western United States. Cons. Res. Rep. No. 17. USDA-ARS, Washington, DC.

Haise, H.R., Donnan, W.W., Phelan, J.T., Lawhon, L.F., Shockley, D.G., 1956. The use cylinder infiltrometers to determine the intake characteristics of irrigated soils. ARS series 41-7. USDA-ARS.
Klute, A., 1965. Laboratory measurement of hydraulic conductivity of saturated soil. In: Black, C.A. (Ed.) Methods of Soil Analysis, Part I, Agronomy 9. American Society of Agronomics, Madison, WI, pp. 210-222.

Linn, D.M., Doran, J.W., 1984. Effect of water-filled pore space on carbon dioxide and nitrous oxide production in tilled and nontilled soils. Soil Sci. Soc. Am. J. 48, 1267-1272.

Lyon, D.J., Stroup, W.W., Brown, R.E., 1998. Crop production and soil water storage in long-term winter wheat-fallow tillage experiments. Soil Tillage Res. 49, 19-27.

Mielke, L.N., Wilhelm, W.W., Richards, K.A., Fenster, C.R., 1984. Soil physical characteristics of reduced tillage in a wheatfallow system. Trans. ASAE 27, 1724-1728.

Miller, R.D., Besler, E., 1977. A quick method for estimating soil water diffusivity functions. Soil Sci. Soc. Am. J. 41, 10201022.

Tanner, C.B., Wengel, R.W., 1957. An air permeameter for field and laboratory use. Soil Sci. Soc. Am. Proc. 21, 662-664.

Unger, P.W., McCalla, T.M., 1980. Conservation tillage systems. Adv. Agron. 33, 1-58.

U.S. Department of Commerce, Weather Bureau., 1961. Rainfall frequency atlas of the United States. Technical Paper No. 40, 61 pp. U.S. Govt. Printing Office, Washington, DC.

Wicks, G.A., Smika, D.E., 1973. Chemical fallow in a winter wheat-fallow rotation. Weed Sci. 21, 97-102. 